\title{
Impact of lameness on the milk production of ewes
}

\author{
${ }^{1}$ Baranovič, Štefan-1,2Tančin, Vladimír-2'Uhrinčat', Michal-2ªčuhová, Lucia- $-^{3}$ Palkovič, Jozef \\ ${ }^{1}$ Department of Veterinary Sciences, Faculty of Agrobiology and Food Resources, \\ Slovak University of Agriculture, Nitra, Slovakia \\ ${ }^{2}$ Animal Production Research Centre Nitra, Lužianky, Slovakia \\ ${ }^{3}$ Department of Statistics and Operations Research, Faculty of Economics and Management, \\ Slovak University of Agriculture, Nitra, Slovakia \\ xbaranovic@is.uniag.sk
}

\section{SUMMARY}

The aim of this study was assessing the impact of lameness on the milk production, somatic cells count and component of milk. We assess also impact of lameness on the order of entry into the milking parlour.

The experiment was carried at the farm, located in northern Slovakia. The farm keeps sheep Improved Valachian. Samples of milk were taken during two periods: May, July. It was taken 428 samples together. We recorded three groups by lameness- strong lame, slightly lame, non-lame ewes. We recorded also the order of entry of ewes into the milking parlour in milking row. The results were mathematically processed using the Microsoft Excel program and statistically evaluated by $S A S$

We found significant statistical differences between months $(P<0.0001)$ in all the above mentioned indicators. In July we recorded 26 ewes with slightly lameness and 18 ewes with strong lameness. Other ewes were non-lame. Non-lame sheep had in July the highest milk yield $(356 \pm 148 \mathrm{ml})$ and the lowest decrease in milk yield from May to July (-206 $\pm 131 \mathrm{ml})$ compared with slightly $(317 \pm 116 \mathrm{ml},-223 \pm 163)$ and strong $(319 \pm 122 \mathrm{ml},-219 \pm 151 \mathrm{ml})$ lame ewes. However, these differences were not statistically significant. We have not identified statistically significant differences between groups in somatic cells count (logxSCC for non-lame: $4.83 \pm 0.608$ in ml, slightly lame: $4.76 \pm 0.653 \mathrm{in} \mathrm{ml,} \mathrm{strong}$ lame $4.71 \pm 0.787 \mathrm{in} \mathrm{ml).} \mathrm{Milk} \mathrm{composition} \mathrm{(fat,} \mathrm{proteins,} \mathrm{lactose)} \mathrm{nor} \mathrm{changes} \mathrm{in} \mathrm{the} \mathrm{composition} \mathrm{of} \mathrm{milk} \mathrm{that} \mathrm{occurred} \mathrm{between} \mathrm{May} \mathrm{and} \mathrm{July}$ were not affected by lameness of ewes. But lameness in July affected the change the order of entry of ewes in the milking parlour in July compared with the order of entry recorded in May.

Keywords: lameness, milk production, ewes, somatic cells count

\section{INTRODUCTION}

Lameness is very serious disease that causes significant financial losses in dairy sheep (Green et al. 2012). Lameness causes less milk yield (Gelasakis et al. 2015) and terrible with welfare (Gougoulis 2010). Impact of lameness was detected also on bodyweight and lamb growth rates and wool growth (Stewart et al. 1984, Marshall et al. 1991).

The reason of lameness is pain that is created the by stimulation of nerve cells (Ley et al. 1995), as a result of various changes to the limbs (mostly on the hooves). Causes of lameness can be broadly classified as genetic, physical injury and infection (Coulon et al. 1996, Warnick et al. 2001, Green et al. 2002, Winter 2004). But lameness can persist also after healing disorders or diseases (Ley et al. 1995).

Impact of lameness on the milk yield was found out (Gelasakis et al. 2010, 2015) but precise information about the losses of milk lame ewes are not known because there are few studies that focus on changes in milk production as a consequence of lameness of ewes.

The aim of this study was assessing the impact of lameness on the milk production, somatic cells count and component of milk. We assess also impact of lameness on the order of entry into the milking parlour

\section{MATERIAL AND METHODS}

The experiment was carried out at the farm, located in northern Slovakia. The farm keeps sheep Improved Valachian. Sheep were housed on deep litter and they grazed on adjacent pastures during the day. The main components of feed were pasturage (ad libitum) and feed concentrate ( $200 \mathrm{~g}$ per animal per day). Milking was performed two times a day in milking parlor $1 \times 24$.

Samples of milk were taken during two periods: May, July. In May, it was taken samples from random sampling ewes with milk yield minimum $300 \mathrm{ml}$ per milking. It was taken 214 samples together. In July milk samples, milk yield and lameness from the same ewes as in May were recorded (project: Kega 006SPU-4/2014). We recorded also the order of entry into the milking parlour in milking row. Number of milking rows was recorded 23 together.

We evaluated the milk yield per milking $(\mathrm{kg})$, fat $(\%)$, protein $(\%)$, lactose $(\%)$, the ratio of fat: protein $(\mathrm{F} / \mathrm{P})$, logarithm from somatic cell count $\left(\operatorname{logx} \mathrm{SCC} \mathrm{ml}^{-1}\right)$ and changes in the milk yield and composition of milk that occurred between May and July. Analysis of milk samples for somatic cell count and essential components has been performed in National Agricultural and Food Center in Lužianky.

We recorded all lameness sheep in entering the milking parlour. Subsequently, we recorded the sheep those lifted (lighten) their limbs during milking. These sheep were marked as "strong lame" sheep. Sheep that lamed in entering the milking parlour but did not lift their limbs during milking were marked as "slightly lame". Sheep that neither did lame in entering the milking parlour nor did lift their limbs during milking were marked as "non-lame".

The results were mathematically processed using the Microsoft Excel program and statistically evaluated by SAS. 


\section{RESULTS AND DISCUSSION}

It was evaluated 214 sheep with an average milk yield of $558 \pm 173 \mathrm{ml}$ milk per milking, a fat content $5.83 \pm 0.96 \%$, a protein content $5.90 \pm 0.50 \%$ and a lactose content $5.17 \pm 0.20 \%$ in May. The average value of the somatic cells count was $5.49 \pm 0.473(\log x$ in $\mathrm{ml})$. For July the milk yield was $349 \pm 143$ ml milk per milking, a fat content $8.88 \pm 1.02 \%$, a protein content of $6.47 \pm 0.52 \%$ and a lactose content $4.86 \pm 0.19 \%$. The average value of the somatic cells count was $4.81 \pm$ $0.628(\log x$ in $\mathrm{ml})$. We found significant statistical differences between months $(\mathrm{P}<0.0001)$ in all the above mentioned indicators. These differences were mainly influenced by the stage of lactation. The decline of logxSCC between months is interesting because it may indicate the health of the udder was better in later lactation than at the beginning of lactation.

In July we recorded 26 ewes with slightly lameness and 18 ewes with strong lameness. Other ewes were non-lame. Non-lame sheep had in July the highest milk yield (356 $\pm 148 \mathrm{ml})$ (Figure 1) and the lowest decrease in milk yield from May to July $(-206 \pm 131 \mathrm{ml})$ compared with slightly $(317 \pm 116 \mathrm{ml},-223 \pm 163 \mathrm{ml})$ and strong $(319 \pm 122 \mathrm{ml},-219 \pm 151 \mathrm{ml})$ lame ewes. However, these differences were not statistically significant.

Lower milk yield for the lame sheep found out by Gelasakis et al. (2010). In the following study Gelasakis et al. (2015) proved the most significant difference in milk yield per milking between lame and non-lame sheep in the $8^{\text {th }}$ week of milking. In our study ewes were milked longer time as 8 weeks and it may affect the non significant differences in milk yield. Also sometimes it is difficult to prove lower production lame animals if their production compared with the average production animals that is non-lame because lameness is often hit the most productive animals which reduce production "only" on the average of the flock (Archer et al. 2010)

Figure 1: Dependence the milk yield per milking from lameness in July

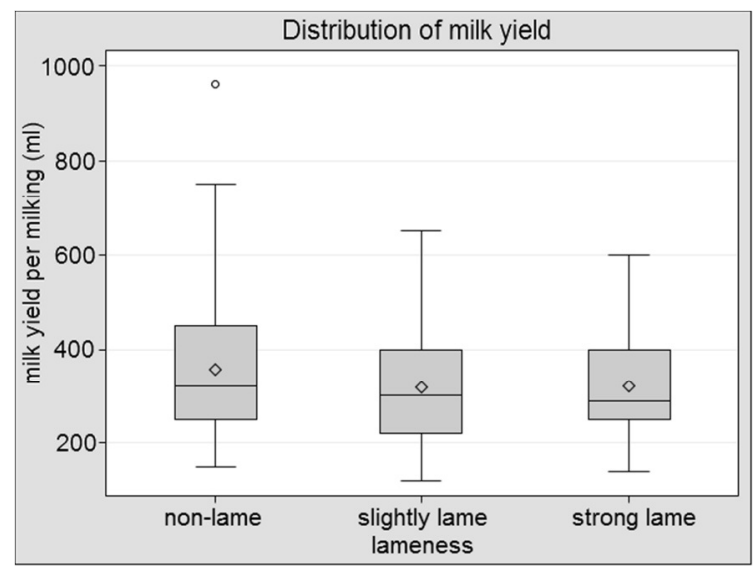

We have not identified statistically significant differences between groups in somatic cell count (logxSCC for non-lame: $4.83 \pm 0.608$ in $\mathrm{ml}$, slightly lame: $4.76 \pm 0.653 \mathrm{in} \mathrm{ml}$, strong lame $4.71 \pm 0.787 \mathrm{in} \mathrm{ml}$ ). The effect of lameness on SCC was found out in herds of cows (Hultgren et al. 2004, Archer et al. 2011). Also our results show some tendency therefore we can expect statistically significant differences in a greater file of animals.

Milk composition (fat, proteins, lactose) nor changes in the composition of milk that occurred between May and July were not affected by lameness of ewes (Table 1).

Contents of milk components and $\operatorname{logxSCC}$ by lameness

\begin{tabular}{|c|c|c|c|c|c|c|c|c|c|c|c|}
\hline \multirow{2}{*}{ Lameness } & \multirow{2}{*}{$\mathrm{N}$} & \multicolumn{2}{|c|}{$\log \mathrm{xSCC}$ in $\mathrm{ml}$} & \multicolumn{2}{|c|}{ Fat $(\%)$} & \multicolumn{2}{|c|}{ Protein $(\%)$} & \multicolumn{2}{|c|}{$\mathrm{F} / \mathrm{P}$} & \multicolumn{2}{|c|}{ Lactose $(\%)$} \\
\hline & & Mean & Std Dev & Mean & Std Dev & Mean & Std Dev & Mean & Std Dev & Mean & Std Dev \\
\hline Non-lame & 170 & 4.83 & 0.608 & 8.85 & 1.025 & 6.47 & 0.535 & 1.37 & 0.157 & 4.86 & 0.193 \\
\hline Slightly lame & 26 & 4.76 & 0.653 & 9.20 & 1.008 & 6.55 & 0.476 & 1.41 & 0.156 & 4.81 & 0.184 \\
\hline Strong lame & 18 & 4.71 & 0.787 & 8.74 & 0.992 & 6.28 & 0.467 & 1.40 & 0.169 & 4.91 & 0.170 \\
\hline
\end{tabular}

Lameness in July affected the change the order of entry of ewes in the milking parlour in July compared with the order of entry recorded in May. There was only a negligible decrease in the order of entry into the parlour in group non-lame sheep (-1.14 milking rows). But lameness sheep in July, entered into the parlour later than in May. Decrease was by group slightly lame -2.87 milking rows and by group strong lame even up to -4.19 milking rows. Statistically significant differences found out between groups strong lame and non-lame sheep $(\mathrm{P}<0.05)$.

\section{CONCLUSIONS}

While information about the impact of lameness on milk production in cows is quite a lot, it was realized few studies in sheep. Our study indicates relationship between lameness and milk production in ewes. We found out some impact between lameness and milk yield while milk components and somatic cells count were not affected. Also impact of lameness on the order of ewe's entry into milking parlour was significant. The further study could be focused to verification impact of lameness on the milk production during all lactation. 


\section{REFERENCES}

Archer, S. C.-Green, M. J.-Huxley, J. N. (2010): Association between milk yield and serial locomotion score assessments in UK dairy cows. Journal of Dairy Science. 93: 4045-4053.

Archer, S. C.-Green, M. J.-Madouasse, A.-Huxley, J. N. (2011): Association between somatic cell count and serial locomotion score assessments in UK dairy cows. Journal of Dairy Science. 94: 4383-4388.

Coulon, J. B.-Lescourret, F.-Fonty, A. (1996): Effect of foot lesions on milk production by dairy cows. Journal of Dairy Science. 79: 44-49.

Gelasakis, A. I.-Arsenos, G.-Valergakis, G. E.-Banos, G. (2015): Association of lameness with milk yield and lactation curves in Chios dairy ewes. Journal of Dairy Research. 2. 82: 193-199.

Gelasakis, A. L.-Arsenos, G.-Valerganis, G. E.-Fortomaris, P.Banos, G. (2010): Effect of lameness on milk production in a flock of dairy sheep. Veterinary Record. 14. 167: 533-534.

Gougoulis, D. A.-Kyriazakis, I.-Fthenakis, G. C. (2010): Diagnostic significance of behaviour changes of sheep: A selected review. Small Ruminant Research. 1. 92: 52-56.

Green, L. E.-Hedges, V. J.-Schukken, Y. H.-Blowey, R. W.Packington, A. J. (2002): The impact of clinical lameness on the milk yield of dairy cows. Journal of Dairy Science. 85: 2250-2256.
Green, L. E.-Kaler, J.-Wassink, G. J.-King, E. M.-Grogono, T. R. (2012): Impact of rapid treatment of sheep lame with footrot on welfare and economics and farmer attitudes to lameness in sheep. Animal Welfare. 1. 21: 65-71.

Hultgren, J.-Manske, T.-Bergstern, C. (2004): Associations of sole ulcer at claw trimming with reproductive performance, udder health, milk yield, and culling in Swedish dairy cattle. Preventive Veterinary Medicine. 4. 62: 233-251.

Ley, S. J.-Waterman, A. E.-Livingston, A. (1995): A field study of the effect of lameness on mechanical nociceptive thresholds in sheep. The Veterinary Record. 4. 137: 85-87.

Marshall, D. J.-Walker, R. I.-Cullis, B. R.-Luff, M. F. (1991): The effect of footrot on body weight and wool growth of sheep. Australian Veterinary Journal. 2. 68: 45-49.

Stewart, D. J.-Clark, B. L.-Jarrett, R. G. (1984): Differences between strains of Bacteroides nodosus in their effects on the severity of foot-rot, bodyweight and wool growth in Merino sheep. Australian Veterinary Journal. 11. 61: 348-352.

Warnick, L. D.-Janssen, D.-Guar, D. C. L.-Gröhn, I. T. (2001): The effect of lameness on milk production in dairy cows. Journal of Dairy Science. 84: 1988-1997.

Winter, A. C. (2004): Lameness in Sheep. Small Ruminant Research. 76: 149-153. 
